\title{
The Network of Bilateral Tax Treaties of the Slovak Republic - Does It Mirror Challenges of the Globalization through Digitalization? A Cluster Analysis Approach
}

\author{
Jana Kubicová ${ }^{1, *}$ \\ ${ }^{1}$ University of Economics in Bratislava, Faculty of national Economy, Department of Finance, \\ Dolnozemská cesta 1, 85235 Bratislava, Slovakia
}

\begin{abstract}
.
Research background: Globalisations and movement of production factors - especially capital and workforces, call for elimination of double international juridical taxation and consequently for negotiation of bilateral tax treaties. Recently global network of bilateral tax treaties has reached immense size.

Purpose of the article: The purpose of this paper is to analyse the network of bilateral tax treaties of the Slovak republic from the point of view of distance and level of development of the Contracting States.

Methods: To reach this goal a cluster analysis method is applied where clustering variables are distance between capital cities of the Contracting States and measures of economic development.

Findings \& Value added: The main finding is that the Slovak republic's bilateral tax treaties are clustered into 11 clusters, and three of them are the most numerous. This implies, that Slovak republic follows certain pattern when chosing Contracting Party. It is also found, that geographical location and distance have diminishing roles. Instead economic development and atractiveness of the country in terms of GDP per capita and total FDI inflow play more important role. These findings prove, that Slovakia no more follows old-fashioned pattern of chosing Contracting Parties based predominantly on distances, instead it adjust its policy of concluding bilateral tax treaties to globalization through digitalisation trend.
\end{abstract}

Keywords: bilateral tax treaties; cluster analysis; geographical location; distance; globalization through digitalization;

JEL Classification: F20; F69; C38; H2O

${ }^{*}$ Corresponding author: jana.kubicova@euba.sk 


\section{Introduction}

Increasing international business brings together also cross-border transactions and financial and income flows. Worldwide principle of taxation implies that income sourced in other country is subject to taxation in the country of residence [1]. Taxing identical income of the same person by the same taxes at the same time in two taxing jurisdictions leads to double international juridical taxation. This in turn causes higher costs of doing business and non-business acitvities in the source country which harms international business, lessens mobility of capital and people. To the constrast searching for double non-taxation can be one reason why multinational companies search for geographical locations with low or no taxation $[2,3]$.

Souvreign States activelly search for ways how to eliminate double international juridical taxation. Even if it is possible to eliminate double income taxation by autonomous measures, like exemption method, bilateral way and cooperation seems to be more beneficial [4]. There are several benefits of bilateral treaties on income and capital taxes: 1 reciprocity; 2 dispute resolution mechanism; 3 predictability; 4 treaty provisions individually suited for needs of individual pair of Contracting States.

Due to the several reasons there was not such an enormous need to conclude bilateral income tax treaties during the period of Austro-Hungarian Empire. First, then in 19th century other types of taxes played key role in tax systems and income taxes had not played crutial role. Second, the geographical size of the Empire was huge and taxes on its territory were unified. Third, transport was based mainly on road or inland waters transport and thus mobility of persons and production factors was weak, which implies that possibility of double international income taxation was negligible. Fourth, there was no presence of modern information technologies and non-cash bank tansactions were not developed. As result chances of double income taxation were negligible, and this explains low inevitability to conclude bilateral income tax treaties then.

History of bilateral tax treaties begins at the end of 19th century and intensifies following the end of the World War I when several modern Empires were dissolved and small national open economies substituted them. This is also when the former Czechoslovakia, predecessor of the nowaday Slovak republic, was established in 1918. In 1920 s, the new small open national economies in Europe adopted their own national tax legislation, including national income taxes. Conflicts of souvereing national taxing jurisdictions were the advent of the double international juridical taxation and consequently a beginning of its elimination by concluding bilateral tax treaties to keep strong economic relations between neighbours.

The League of Nations had initiated preparation of the Model Tax Convention and in 1921 proposed its first version. Preparation works had been continuing also in the period between two World Wars and it was coronated at the beginning of 1960s when the OECD MTC was suggested to apply when negotiating individual bilateral tax treaties. Since then Souvereign States around the world have signed more than 3000 individual bilateral tax treaties and they all together form a network the Orb is encircled by. However, the era of digitalisation calls for rethinking of the international tax regime [5, 6, 7].

This paper focuses on the bilateral tax treaties effective in the Slovak republic. Its network of bilateral tax treaties currently includes 71 bilateral tax treaties. They were signed and adopted in two ways: first, by the former Czechoslovakia - some tax treaties have been still effective because of succession. Second, tax treaties negotiated and ratified by the souvereign Slovak republic. Fifteen tax treaties were already amended according the OECD Multilateral Convention to Implement Tax Treaty Related Measures to Prevent 
BEPS (hereafter OECD MLI) as Slovakia is one of its signatories' countries. Bilateral tax treaties that implemented the OECD MLI contain several serious revisions with which business community will have to contend [8].

The aim of this paper is to study network of the bilateral tax treaties of the Slovak republic and the underlying policy behind network structure. The paper focuses on the analysis of the geografphical location of Contracting States, taking into account also level of development and an attractivness of them measured by foreign direct investment inflows.

The main question of interest is whether there is any watchful strategy of the Slovak government which lies behind the existing network of treaties, whether it is possible to identify some pattern and common denominators of the tax treaty Countries. To reach the goal I investigate whether there is any evidence of different groups of Contracting States with common denominators. Should there be find certain pattern will mean that there is rational strategy of the Slovak government behind building the network of tax treaties. I would like to determine this strategy and uncover the common denominators of groups of Contracting States Slovak government chose to negotiate tax treaties with. To meet the goal a clustering method is applied.

Results of analysis may help understand whether strategy and policy behind negotiation and conclusion of bilateral tax treaties of the Slovak republc correspond with modern needs, especially with the emergence of digital business in information era. It may help to assess whether such a pattern of selection of states for concluding bilateral tax treaties is in line with economic challenges and interests of the Slovak Republic. Specifically the results may help us to understand, whether it supports the expansion of Slovak companies or individuals into countries, whether it supports economic growth or the inflow or outflow of FDI.

\section{Hypothesis, Data and Methodology}

\subsection{Hypothesis}

Bilateral tax treaties ratified by the Slovak republic is published in Collection of Laws of the Slovak republic, which is the source of information about a number of existing treaties. Figure 1 shows number of tax treaty parties and their percentage shares on the total number of bilateral tax treaties concluded by the Slovak republic. Figure 2 presents structure of the network of bilateral tax treaties by income groups. 


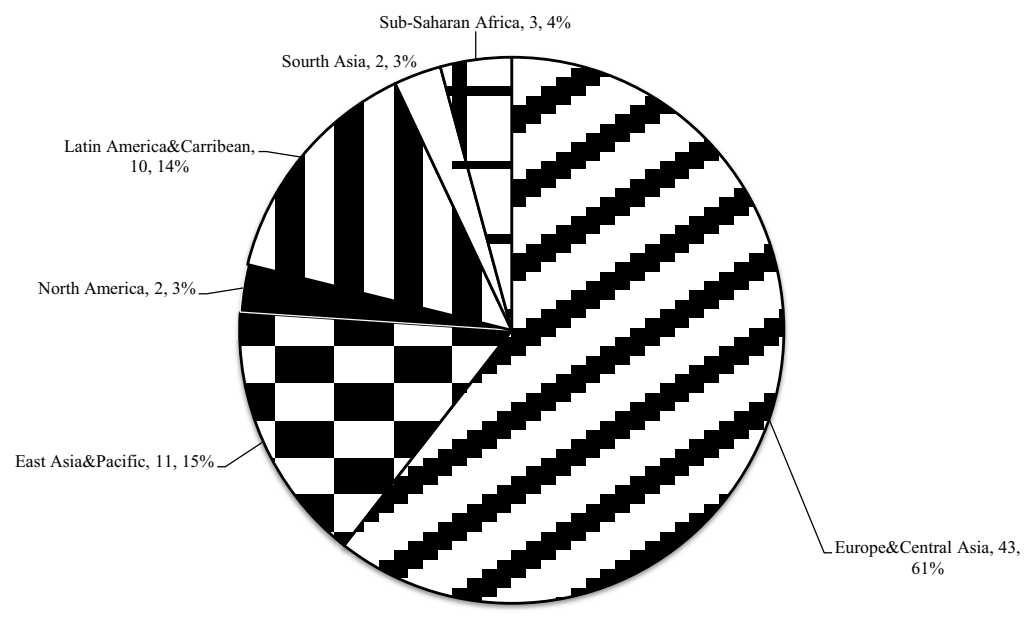

Fig. 1. Structure of the network of bilateral tax treaties of Slovakia by georgaphical regions.

Legend: first number represents number of countries and a second number represents per centage share on the total number of treaties.

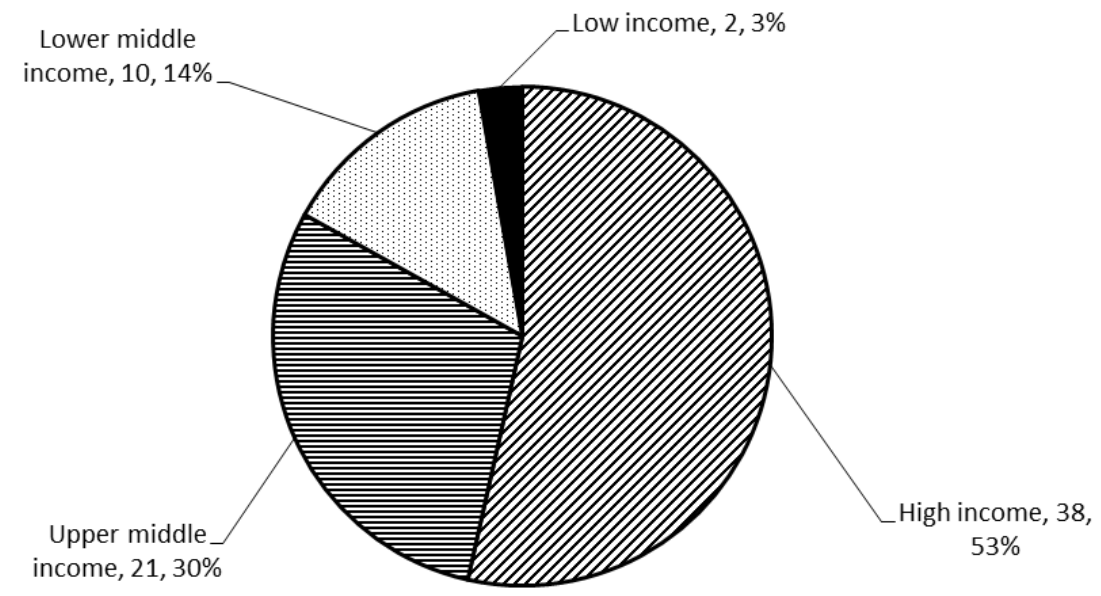

Fig. 2. Structure of the network of bilateral tax treaties of Slovakia by income groups.

Legend: first number represents number of countries and a second number represents per centage share on the total number of treaties.

To summarise, data shows, that geographical location of majority of Concracting States, namely 61 per cent, is in Europe and Central Asia. By data observation there is no doubt, that most of the bilateral income tax treaties Slovakia signed with its closest neighbours. Data obsaervation also indicates, that the network of bilateral tax treaties is comprised mainly from the high income countries (53 per cent).

Based on the historical evolution, data observation and description of data using pie charts (Fig. 1 and Fig. 2). I hypothetise that the Slovak republic concludes bilateral tax treaties mainly with its closest geographical neighbours i.e. countries with which it joins 
common borders and countries that are geographically located mainly in Europe - which follows old-fashion strategy adopted after the World War I. If a Contracting State is not the closest Slovakia's neigbour, it is likely, that the Contracting State is a developed country. Thirdly, attractiveness of the Congracting State in terms of the volume of foreign direct investment inflow does not play significant role in the policy of chosing tax treaty Partner.

\subsection{Data}

To find out whether there is any pattern which represent an underlying conscious policy background behind the network of the bilateral tax treaties concluded by the Slovakia's government, it was employed a cluster analysis method.

To identify geographical stucture I use distances between capital city of Slovakia, Bratislava, and capital city of bilateral tax treaties' parties. The distance is measured in kilometers between main international airports of two cities. The source of data on distance is distance calculator [9]. To measure level of economic developement of tax treaty Party data on gross domestic product per capita were employed. The source of data is World Bank database .

To measure attractiveness of bilateral tax treaty Party I employ data about the total foreign direct investment inflow into the tax treaty Party and I use data published by The World Bank. Table 1 presents variables and data sources.

Table 1. Data and their sources.

\begin{tabular}{|c|c|c|c|}
\hline Variable & Data & Unit & Source \\
\hline BTTij & BTT between $i$ and $j$ & individual & $\begin{array}{c}\text { Coll. of Laws of the Slovak } \\
\text { republic }\end{array}$ \\
\hline Geo & $\begin{array}{c}\text { Distance between Bratislava and } \\
\text { capital city of treaty party capital } \\
\text { city }\end{array}$ & $\mathrm{km}$ & Distancecalculator.globefeed.com \\
\hline Development & GDP per capita & US\$ & World Bank database \\
\hline FDI & $\begin{array}{c}\text { net } \\
\text { total FDI, net inflows into the } \\
\text { Contracting State (BoP, current } \\
\text { US\$) }\end{array}$ & $\begin{array}{c}\text { (BoP, } \\
\text { current } \\
\text { US\$ }\end{array}$ & World Bbank database \\
\hline
\end{tabular}

\subsection{Methodology}

The aim of this paper is to analyze the underlying pattern behind the policy of the Slovak Republic in concluding bilateral tax treaties. In particular, the aim is to find out whether there are any groups of Contracting States with common features and similarities the Slovak republic goverment prefers to conclude bilateral tax treaties with. To complete the task the method of cluster analysis was employed.

There are different approaches to the cluster analysis, and in general it is possible to distinguish three main approaches: hierarchical [10], non-hierarchical and model based methods [11] of the cluster analysis [12,13,14,15].

To investigate similarities in the structure of tax treaty network of the Slovak republic it was employed hierarchical clustering and to measure distances between observations the single linkage clustering method was employed [16].

Prior to execution of the cluster analysis itself the collected data on distances, GDP per capita and FDI net inflows were standardised as units of measurement were not 
comparable. To standardize the data the mean was substracted from original data and then divided by standard deviation for each variable. Having standardized data, preliminary to cluster analysis, the profile diagram was made to see whether clusters is possible to find.

\section{Results and Discussion}

The outcome of the hierarchical cluster analysis based on similarities of geographical distance from the capital city of Slovakia, economic development measured by GDP per capita, and FDI inflows is that 71 Contracting States are clustered into eleven different clusters.

Figure 3 presents a quantil chart of clusters of tax treaty Parties of the Slovak republic and Figure 4 shows a histogram which presents frequency of Countries in each of eleven clustters. Both figures prove that there are three main groups of Contracting States the Slovak government chosen to sign bilateral tax treaties with.

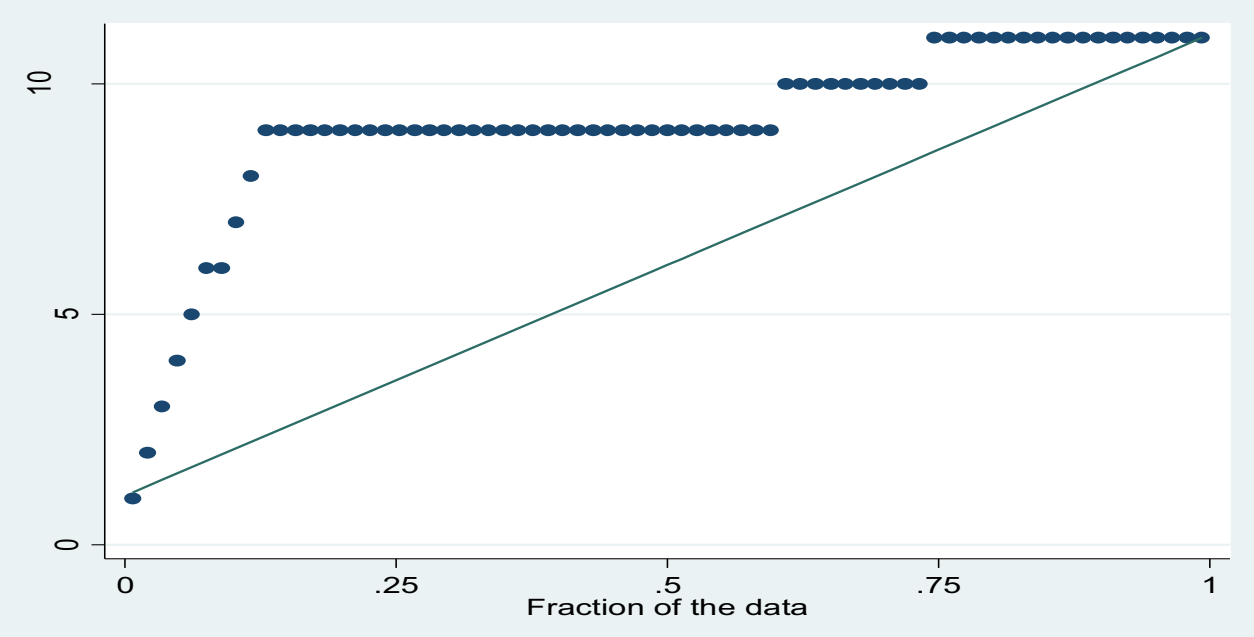

Fig. 3. A Quantil chart of clusters of tax treaty Parties of the Slovak Republic.

The results of cluster analysis prove that there is clear pattern that underlines the policy of the Slovak republic when chosing countries to negotiate and conclude bilateral tax treaties. Namely, there are three main clusters of countries that have common features and are similar. The first cluster of Contracting Parties is the most numerous - it comprises 35 of total of 71 bilateral treaty parties. 


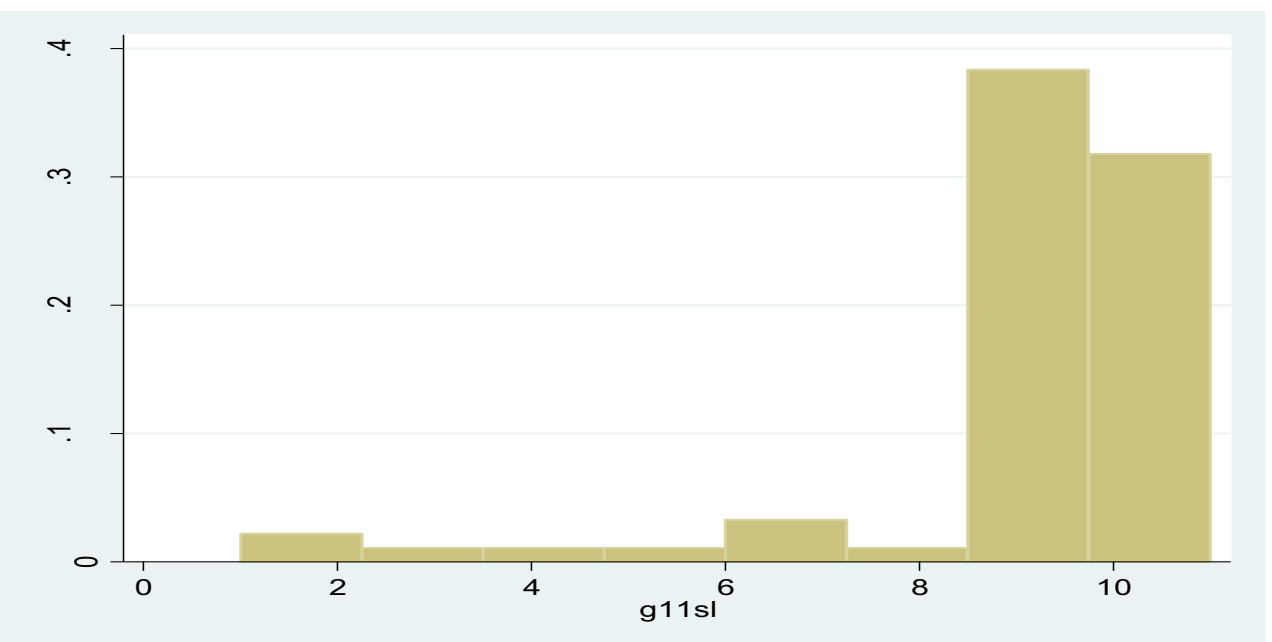

Fig. 4. Bar chart of 11 clusters of Contracting States.

The most numerous cluster (number 9) comprises of 35 out of 71 Contracting States, namely Austria, Ethiopia, Latvia, Romania, Malaysia, Tunisia, Moldova, Greece, Lithuania, Turkmenistan, Luxembourg, Poland, Sri Lanka, Sweden, Bosnia and Herzegovina, Bulgaria, South Africa, Estonia, Cyprus, Iceland, Serbia, Portugal, Croatia, Armenia, Belarus, Mongolia, Czech republic, Georgia, United Arab Emirates, Mongolia, Denmark, Ukraine, Uzbekistan, Montenegro, Slovenia . The second most numerous cluster (cluster 10) comprises of 10 Contracting States, they are namely Hungary, Vietnam, Finland, Kazakhstan, Belgium, Switzerland, Netherlands, Norway, Kuwait, Libya. The third most numerous cluster (number 11) puts into one group following Contracting States: Japan, United States, Indonesia, Germany, Syrian Arab Republic, Mexico, Brazil, Taiwan, Italy, India, Canada, France, Korea, Rep., Turkey, United Kingdom, Spain, China.

\section{Conclusion}

This paper analyses network of bilateral tax treaties concluded by the Slovak republic. The purpose was to analyse network of bilateral tax treaties from the point of geographical location, level of develepment of Contracting States and attractiveness in terms of total foreign invesmtent inflows. To reach this goal a hierarchical cluster analysis method with single linkage distance measuring was employed.

The main finding is that Contracting Parties of the Slovak republic's bilateral tax treaties are clustered mostly into 3 clusters. This proves that there is clear pattern which underlines the policy behind the network of bilateral tax treaties of the Slovak republic. The most numerous clusters include countries which are not always the closest neighbours of the Slovak republic. Based on the analysis of the members of the first three most numerous clusters, it is also possible to conclude, that a geographical location of a Contracting State is important, however does not play the first, key and the most important role when chosing the Contracting Party. This means, that the Slovak republic no more follows the oldfashioned policy of concluding tax treaties only with the closest neigbours, to the contrast there is noticeable departure from this policy towards global expansion. These results suggest that level of the economic development outplays geographical position of the Contracting State, and geographical position of the Country has becoming of secondary in 
comparison to economic development and attractiveness of the Contracting State in terms of FDI inflow. The closer look on the members of the rest of eleven clusters however indicates that there are also Contracting States with specific and not similar features - thus chosen not based on the pattern.

Globalilzation through digitalization makes challenges to the structure of the network of bilateral tax treaties as digital technologies enable doing business and earn income in the Slovak republic without physical presence. Transport costs and geographical location have become less important and Slovak republic strategy captured this trend.

This work was supported by funds granted by The Ministry of Education of the Slovak republic under the number VEGA No 1/0779/19 Challenges of digitization of the economy in the field of taxation, possible solutions and their assumptions.

\section{References}

1. Kohlhase, S., Pierk, J. (2020). The effect of a worldwide tax system on tax management of foreign subsidiaries. Journal of International Business Studies, 51, 1312-1330.

2. Akamah, H., Hope, O.-K., Thomas, W. B. (2018). Tax havens and disclosure aggregation. Journal of International Business Studies, 49, 49-69.

3. Allred, B., Findley, M. G., Nielson, D., Sharman , J. C. (2017). Anonymous shell companies: A global audit study and field experiment in 176 countries. Journal of International Business Studies, 48, 596-619.

4. Sunita, J. (2020). Tax in history: The 100th anniversary of international institutions and international taxation. Intertax, 48(10), 929-933.

5. Ting, A., Gray, S. J. (2019). The rise of the digital economy: Rethinking the taxation of multinational enterprises. Journal of International Business Studies, 50, 1656-1666.

6. Kind, H. J., Koethenbuerger, M. (2018). Taxation in digital media markets. Journal of Public Economy Theory, 20(1), 22-39.

7. McGaughey, S. L., Raimondos, P. (2019). Shifting MNE taxation from national to global profits: A radical reform long overdue. Journal of International Business Studies, 50(9), 1668-1683.

8. Yehoshua, S., Zeev, W., Reika, S. (2020). The newly revised Israel-Japan double taxation convention: The MLI's impacts and implications. Intertax, 48(10), 904-92.

9. Distance Calculator. (June 2020). Distancecalculator. Retrieved from: distancecalculator.globefeed.com.

10. Ward, J. J. (1963). Hierarchical grouping to optimize an objective function. Journal of the American Statistical Association, 58(301), 236-244.

11. Fraley, C., Raftery, A. E. (2002). Model-based clustering, discriminant analysis, and density estimation. Journal of the American Statistical Association, 97(458), 611-631.

12. Afifi, A., May, S., Clark, V. A. (2012). Practical multivariate analysis. Taylor and Francis Group LLC.

13. Forgy, E. W. (1965). Cluster analysis of multivariate data: Efficiency versus interpretability of classifications. Biometrics, 21(3), 768-769. 
14. Mooi, E., Sarstedt, A. (2011). Cluster analysis. A Coincise Guide to Market Research (pp. 237-284). Berlin: Springer-Verlag.

15. Tibshirani, R., Walther, G., Hastie, T. (2001). Estimating the number of clusters in a data set via the gap statistic. Journal of the Royal Statistical Society: Series B (Statistical Methodology), 63(2), 411-423.

16. Rabe-Hesketh, S., Everitt, B. S. (2007). A handbook of statistical analyses using stata. Boca Raton: Taylor and Francis Group. 